\title{
Severe hypophosphataemia during recovery from acute respiratory acidosis
}

\author{
TOMMY L STORM
}

\begin{abstract}
Three elderly patients with established chronic obstructive airways disease were admitted with a short history of increasing dyspnoea and tiredness and (in two cases) a deterioration in mental state. Acute respiratory acidosis was diagnosed and mechanical ventilation instituted.

Two hours after beginning mechanical ventilation the mean arterial pH had risen to $7 \cdot 40$, but all patients showed a dramatic fall in the serum phosphate concentration (lowest value $0.3 \mathrm{mmol} / 1(0.9 \mathrm{mg} / 100 \mathrm{ml})$ ) accompanied by a low urinary excretion of phosphate. No patient could tolerate withdrawal of mechanical ventilation until the serum and urinary concentrations of phosphate had returned to normal.

Recovery from acute respiratory acidosis should be added to the list of conditions associated with severe hypophosphataemia.
\end{abstract}

\section{Introduction}

In an extensive review of hypophosphataemia, Knochel described several clinical conditions in which the serum phosphate concentration may be severely depressed $(<0.32 \mathrm{mmol} / \mathrm{l}$; $<1.0 \mathrm{mg} / 100 \mathrm{ml}){ }^{1}$ These included withdrawal from alcohol, diabetes mellitus, pharmacological phosphate binding, recovery phase after severe burns, hyperalimentation, nutritional recovery syndrome, severe respiratory alkalosis, and after renal transplantation. Hypophosphataemia may be asymptomatic, but profound phosphate depletion has numerous clinical manifestations and may be life threatening.

Low serum phosphate concentrations have been implicated as a cause of respiratory failure, ${ }^{2}{ }^{3}$ but severe hypophosphataemia occurring during recovery from acute respiratory acidosis has not been reported.

\section{Case histories}

Case 1-A 61 year old woman presented with a one week history of increasing dyspnoea and tiredness and deteriorating mental state. She had suffered from chronic obstructive airways disease for 15 years. Before admission she had taken no medication other than mild analgesics. Physical examination showed an unconscious woman with a blood pressure of $190 / 90 \mathrm{~mm} \mathrm{Hg}$, a regular pulse rate of 100 beats $/ \mathrm{min}$, a temperature of $36 \cdot 1{ }^{\circ} \mathrm{C}$, and central cyanosis and tachypnoea. A chest radiograph showed no sign of pneumonia. Results of arterial blood gas measurements were: $\mathrm{pH} 7 \cdot 06$, carbon dioxide pressure $\left(\mathrm{PCO}_{2}\right) 21.0 \mathrm{kPa}(158 \mathrm{~mm} \mathrm{Hg})$, and actual bicarbonate $28.5 \mathrm{mmol}$ $(\mathrm{mEq}) / 1$. Serum phosphate concentration was $2.6 \mathrm{mmol} / 1(8.0 \mathrm{mg} / 100$ $\mathrm{ml}$ ) (normal 0.8-1.5 mmol $/ 1 ; 2.5-4.6 \mathrm{mg} / 100 \mathrm{ml}$ ).

Case 2-A 74 year old woman had had a history of chronic obstructive airways disease for 20 years. She had taken no drugs before admission. During the three weeks before admission she had suffered increasing dyspnoea and tiredness, and for the last three days a deteriorating mental state. On examination she was found to be stupor-

\footnotetext{
Department of Medicine, Sundby Hospital, Italiensvej 1, DK-2300 Copenhagen S, Denmark
}

TOMMY L STORM, MD, research fellow ous with cyanosis and severe polypnoea. She was using her accessory muscles for respiration. Blood pressure was $140 / 80 \mathrm{~mm} \mathrm{Hg}$, pulse rate $120 / \mathrm{min}$, and temperature $38.3^{\circ} \mathrm{C}$. A chest radiograph showed right inferior pneumonia. Arterial blood gas measurements were: $\mathrm{pH}$ $7 \cdot 20, \mathrm{PCO}_{2} 13.3 \mathrm{kPa}(100 \mathrm{~mm} \mathrm{Hg})$, and actual bicarbonate $29 \cdot 2$ $\mathrm{mmol} / \mathrm{l}$. Serum phosphate concentration was $1.6 \mathrm{mmol} / 1(5.0 \mathrm{mg} / 100$ $\mathrm{ml})$. She was given penicillin for the pneumonia.

Case 3-A 70 year old woman with a history of chronic obstructive airways disease and cor pulmonale had suffered from increasing dyspnoea and tiredness for two weeks before admission. She had been taking bendrofluazide $5 \mathrm{mg}$ daily for right sided heart failure. Examination showed a blood pressure of $140 / 90 \mathrm{~mm} \mathrm{Hg}$, pulse rate $104 / \mathrm{min}$, and temperature $37.3^{\circ} \mathrm{C}$. A chest radiograph showed no sign of pneumonia but the heart was slightly enlarged. Arterial blood gas measurements were: $\mathrm{pH} 7 \cdot 23, \mathrm{PCO}_{2} 11.9 \mathrm{kPa}(89 \mathrm{~mm} \mathrm{Hg})$, and actual bicarbonate $32.6 \mathrm{mmol} / 1$. Serum phosphate concentration was $1.2 \mathrm{mmol} / \mathrm{l}$ $(3.7 \mathrm{mg} / 100 \mathrm{ml})$.

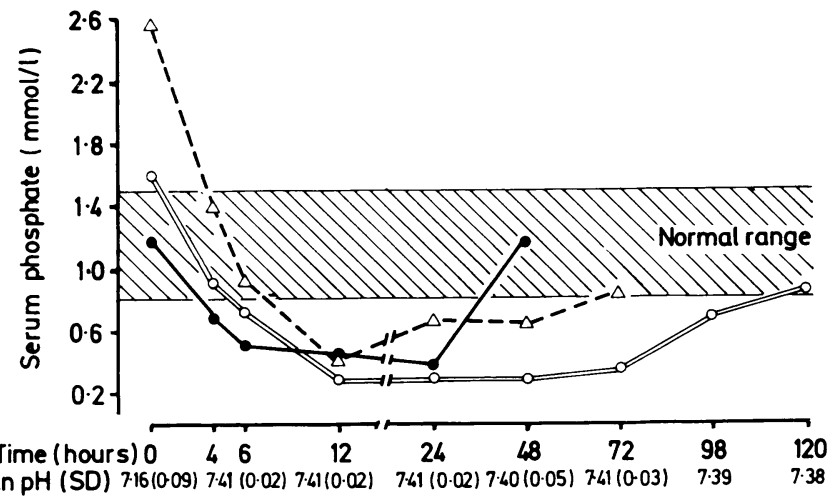

Changes in serum phosphate concentrations in cases $1(\Delta), 2(0)$, and $3(0)$ after starting mechanical ventilation (at zero hour). (Phosphate: $1 \mathrm{mmol} / 1 \approx 3$ $\mathrm{mg} / 100 \mathrm{ml}$.)

\section{Treatment and results}

On admission routine blood tests (including measurements of serum calcium and magnesium concentrations and creatine phosphokinase activity) gave normal results in all patients. The patients were intubated and mechanical ventilation instituted (time zero).

Two hours after beginning mechanical ventilation the mean arterial $\mathrm{pH}$ had risen to 7.40 (SD 0.03) $\left(\mathrm{Po}_{2}\right.$ and $\mathrm{PCO}_{2}$ normal). All patients showed a rapid fall in serum phosphate concentrations, the lowest value recorded being $0.3 \mathrm{mmol} / 1(0.9 \mathrm{mg} / 100 \mathrm{ml})$ (figure). Urinary phosphate excretion during the first 24 hours of mechanical ventilation ranged from 3.8 to $9.4 \mathrm{mmol}(0.1$ to $0.3 \mathrm{~g}) / 24 \mathrm{~h}$ (normal $16-48 \mathrm{mmol}(0.5-$ $1.5 \mathrm{~g}) / 24 \mathrm{n}$ ). No patient was given intravenous glucose during the first 24 hours of mechanical ventilation, and none received glucocorticoids, antacids, or phosphate replacement. Several unsuccessful attempts to withdraw mechanical ventilation were made over the next two to four days. Periods off the ventilator lasted from 10 minutes to one hour. Once the serum and urinary phosphate concentration had returned to normal the patients were no longer dependent on mechanical ventilation.

\section{Discussion}

The profound hypophosphataemia in these patients could not be explained by the usual causes of hypophosphataemia. ${ }^{1}$ Respiratory alkalosis lowers serum phosphate concentrations 
acutely via transcellular shifts ${ }^{4}$ but there was no evidence that any patient was hyperventilated during the intubation period.

Acidosis depresses glycolytic activity, ${ }^{5}$ raises the serum phosphate concentration, and thereby intensifies excretion in the urine. Thus severe phosphate deficiency may occur in respiratory acidosis. When the $\mathrm{pH}$ returns to normal hypophosphataemia may develop because of increased shifts of phosphorus from the blood compartment into the intracellular compartment secondary to increased glycolytic activity.

Phosphate depletion is associated with a decreased concentration of adenosine triphosphate in skeletal muscle and may result in muscle weakness. Phosphate deficiency and hypophosphataemia lead to mobilisation of bone mineral, ${ }^{1}$ which might explain the spontaneous return to normal of the serum phosphate concentrations. Furthermore, probably intracellular adenosine triphosphate concentrations return to normal together with serum phosphate values, thus explaining why the patients were dependent on mechanical ventilation until the serum phosphate concentration came within the normal range.

Newman et al reported that patients with hypophosphataemia responded dramatically to intravenous repletion within hours. ${ }^{3}$
In this series, however, the spontaneous changes in serum phosphate concentrations seen during recovery from acute respiratory acidosis (figure) suggest that phosphate replacement is not invariably necessary as a standard treatment of respiratory failure associated with low concentrations of serum phosphate. Nevertheless, patients should be monitored by repeated serum phosphate determinations, especially when it is difficult to achieve successful weaning.

Recovery from acute respiratory acidosis should be added to the list of conditions associated with severe hypophosphataemia.

\section{References}

' Knochel JP. Hypophosphatemia. West $\mathcal{F}$ Med $1981 ; \mathbf{1 3 4}: 15-26$.
2 Brown EL, Gwynne Jenkins BA. A case of respiratory failure complicated by acute

hypophosphataemia. Anaesthesia $1980 ; 35: 42-5$.
Newman JH, Neff TA, Ziporin P. Acute respiratory failure associated with hypophosphatemia. $N$ Engl $₹$ Med $1977 ; 296: 1101-3$.

phosphatemia. $N$ Engl
Mostellar ME, Tuttle EP. Effects of alkalosis on plasma concentration and urinary excretion of inorganic phosphate in man. $\mathcal{f}$ Clin Invest $1964 ; 43: 138-49$.

Relman AS. Metabolic consequences of acid-base disorders. Kidney Int 1972;1 347-59.

(Accepted 10 May 1984)

\title{
Increasing saliva (free) oestriol to progesterone ratio in late pregnancy: a role for oestriol in initiating spontaneous labour in man?
}

\author{
HUGH H G MCGARRIGLE, GILLIAN C L LACHELIN
}

\begin{abstract}
Oestriol and progesterone concentrations were measured in samples of saliva obtained daily from six normal women during the final four weeks before the spontaneous onset of labour. Progesterone concentrations were found to plateau whereas oestriol concentrations continued to rise so that the mean ratio of saliva oestriol to progesterone increased from 0.80 to 1.43 between 29 days and one day before labour. Saliva oestriol concentrations were 15 times higher than saliva oestradiol concentrations.

As saliva steroid concentrations reflect the unbound unconjugated (free) plasma steroid concentrations these data suggest that a changing ratio of oestriol to progesterone may play a part in initiating spontaneous labour in man.
\end{abstract}

\section{Introduction}

The onset of labour in sheep and some other mammalian species is preceded by a rise in the maternal plasma oestrogen to progesterone ratio. ${ }^{1-3}$ No consistent change in the plasma unconjugated oestradiol to progesterone ratio has been shown before the onset of labour in the rhesus monkey or in man. ${ }^{4-\text {; }}$

\footnotetext{
Department of Obstetrics and Gynaecology, School of Medicine, University College London, London WC1E 6HX

HUGH H G MCGARRIGLE, BSC, senior biochemist

GILLIAN C L LACHELIN, MD, FRCOG, senior lecturer

Correspondence to: $\mathrm{Mr} \mathrm{H} \mathrm{H} \mathrm{G} \mathrm{McGarrigle.}$
}

Plasma unconjugated steroid concentrations, however, consist of both the protein bound steroid and the biologically available unbound or "free" steroid, and as the percentage binding of the oestrogens and of progesterone to plasma proteins differs considerably $^{8}$ ( $\mathrm{H} \mathrm{H} \mathrm{G} \mathrm{McGarrigle,} \mathrm{G} \mathrm{C} \mathrm{L} \mathrm{Lachelin,} \mathrm{paper} \mathrm{presented}$ at 2nd joint meeting of British endocrine societies, April 1983 (abstract 64)), real changes in the ratios of the unbound unconjugated steroids cannot be shown by measurements of the total plasma unconjugated steroid concentrations.

We and others have shown that saliva oestriol, oestradiol, and oestrone concentrations in pregnancy reflect the plasma unbound unconjugated or free oestrogen concentrations ${ }^{9}$ ( $H$ H G McGarrigle, G C L Lachelin, paper presented at 2nd joint meeting of British endocrine societies, April 1983 (abstract 64)), and similar findings have been reported for saliva progesterone and plasma unbound progesterone concentrations in late pregnancy. ${ }^{10}$ We therefore measured saliva oestriol and progesterone concentrations in daily samples as well as saliva oestrone and oestradiol concentrations in weekly samples collected during the four weeks preceding the spontaneous onset of human labour, and we examined the ratios of oestriol, oestrone, and oestradiol to progesterone in these samples.

\section{Patients and methods}

Saliva samples were collected at intervals during pregnancy and daily during the four weeks before the spontaneous onset of labour by six normal pregnant women who delivered a healthy infant of normal birth weight vaginally after 37 weeks' gestation. The $5 \mathrm{ml}$ samples were collected in plastic universal containers at about 1000 after the mouth was rinsed with water. They were stored at home in a freezer and then in the laboratory at $-40^{\circ} \mathrm{C}$ until they were assayed.

All the steroids were measured by radioimmunoassay. Before assay all saliva samples were thawed, mixed, and centrifuged at $2000 \mathrm{~g}$ for 10 minutes. For measurement of oestriol and progesterone $50 \mu \mathrm{l}$ 